\title{
Menjelajah Kultur Majapahit, Mencari “Identitas” Seni Rupa Kontemporer Jawa Timur
}

\section{Bramantijo}

Sekolah Tinggi Kesenian Wilwatikta Surabaya

\section{Abstract}

The identity of Indonesian art is loaded with political contents in the interests of harmony. Indentity becomes the differentiator and positioning in artwords. East Java gets the fortunes to be the locus of Majapabit and heritage of the Majapabit culture, but the atmosphere of contemporary art gives artists of freedom to explore the variety of traditional cultures in various loci and make as identity. The sole recognition of a culture by a group community is no longer relevant. The other way, it occurs the ability of artists to discover the characteristics of traditional cultures and to present it typically as a differentiator with other artists.

Keywords: Majapabit, identity, Contemporary Art

\section{PENGANTAR}

Wacana "identitas" menjadi krusial ketika berada dalam khasanah kesejagatan atau globalisasi. Kesenian sebagai komponen kebudayaan menjadi ujung tombak membangun identitas suatu bangsa. Identitas dalam seni rupa Indonesia menjadi wacana dominan ketika kita berhadapan dengan dominasi seni rupa Barat sebagai kiblat seni rupa dunia. Identitas juga menjadi sangat politis ketika digunakan sebagai alat perjuangan dan membangkitkan solidaritas, sebab itu pembicaraan tentang identitas menjadi topik yang seakan tidak ada habisnya. Dalam seni rupa Indonesia wacana identitas erat berkaitan dengan tradisi-tradisi yang berkembang di Nusantara. Lokalitas menjadi tawaran yang mampu menjadi pembeda ketika bersejajar dengan seni rupa moderen Barat pada umumnya, meskipun dianggap di luar arus utama. Pada perkembangan berikutnya, seni rupa kontemporer yang membawa kecenderungan postmoderen justru menempatkan spirit tradisi sebagai bagian dari wacana identitas dan eksplorasi bentuk dan makna.

Jawa Timur sebagai wilayah budaya yang bersinggungan dengan wilayah perkembangan seni rupa kontemporer Indonesia, memiliki potensi kuat untuk hadir sebagai pusat perkembangan seni rupa kontemporer yang ditopang spirit tradisi kejayaan Majapahit. Majapahit adalah kerajaan yang berpusat di Jawa Timur, yang berdiri dari sekitar tahun 1293 hingga1550 M. Majapahit mencapai puncak kejayaannya dan menjadi kemaharajaan raya serta menguasai wilayah yang luas di Nusantara pada masa kekuasaan Hayam Wuruk, yang berkuasa dari tahun 1350 hingga1389. Kerajaan Majapahit adalah kerajaan Hindu-Buddha terakhir yang menguasai Nusantara dan dianggap sebagai salah satu dari negara terbesar dalam sejarah. Menurut Negarakertagama, kekuasaannya terbentang di Jawa, Sumatra, Semenanjung, Malaya, Kalimantan, hingga Indonesia Timur, meskipun wilayah kekuasaannya masih diperdebatkan. 
Berdasar data arkeologi dan sejarah, yang belum pernah terjadi dalam sejarah seni tinggalan budaya Majapahit menyebar hampir di pada masa sebelumnya (modern art). Kriteria seluruh Nusantara dan mempengaruhi menetapkan pengertian seni kontemporer perkembangan kebudayaan, salah satunya dimaksudkan agar tidak memiliki pengertian kesenian pada masa berikutnya. Terutama di Jawa Timur - tempat banyak ditemukan sisa sisa budaya Majapahit - penciptaan seni kontemporer dengan memakai unsur-unsur tinggalan Majapahit menjadi isu kejatidirian yang strategis.

Permasalahan isu kejatidirian Seni Rupa Kontemporer yang telah disebutkan di atas menjadi fokus pembahasan pada makalah ini. Bagaimana masalah kejatidirian tersebut terkait dengan kesejarahan, penilaian-penilaian estetis, dan pemikiran-pemikiran estetika Seni Rupa Kontemporer, serta bagaimana strategi representasinya?

\section{A. Memahami Wacana Seni Rupa Kontemporer}

Istilah Seni Rupa Kontemporer di dalam sejarah perkembangan seni rupa digunakan seiring dengan terjadinya perubahan besar dalam praktek penciptaan karya-karya seni rupa. Sebelumnya, istilah 'kontemporer', mengacu pada arti kata 'contemporary', hanya sekedar digunakan untuk menyebutkan seni 'masa kini', seni yang baru, yang tidak ada kaitannya dengan kecenderungan corak atau gaya karya seni itu sendiri. Arthur Danto (1995; 11) memberikan penjelasan bahwa istilah "kontemporer" dalam "Contemporary Art' tidak sekedar berfungsi sebagai temporal sense, tetapi menjadi salah satu kriteria yang mengandung pengertian bahwa seni kontemporer adalah seni yang dihasilkan dalam sebuah struktur produksi

sekedar segala praktek seni rupa masa kini, bisa dilihat dari praktek seni rupa yang memiliki kecenderungan postmoderen. Lebih lanjut Danto menyatakan bahwa, istilah contemporary art tidak terlalu kokoh maknanya dan tidak jelas batasannya, karena seni rupa kontemporer dipahami sebagai seni rupa yang sedang berlangsung dan belum teruji oleh waktu. Namun demikian tidak semua seni rupa kontemporer adalah seni postmoderen.

Postmoderenisme menggambarkan gerakan-gerakan yang berasal dari dan bereaksi terhadap kecenderungan moderenisme (Krauss, 1985; 8). Dasar dari paham postmoderenisme di antaranya adalah pengingkaran terhadap peran kebudayaan Barat (sebagai penyusun narasi besar sejarah peradaban) sebagai pusat, sedangkan budaya lain berada di pinggiran. Spirit penting postmoderenisme adalah pluralisme, yang mengakui keberadaan berbagai bentuk ekspresi seni yang beragam, yang dimiliki entitas budaya-budaya suku bangsa yang terdapat di berbagai penjuru dunia.

Dengan demikian jelas, bahwa prinsip dasar postmoderenisme sebenarnya adalah penentangan terhadap konsep moderenisme, yang meyakini universalisme sebagai kebenaran yang tunggal dan absolut. Sebaliknya, pluralisme memandang setiap perwujudan budaya memiliki nilai kebenarannya masing-masing. Bisa dimengerti, apabila pemikiran postmoderenisme 
ini mendapat sambutan antusias, terutama oleh bangsa-bangsa di luar Eropa dan Amerika (bangsa-bangsa non-Barat). Momentum ini seakan menjadi momentum kebangkitan bagi bentuk seni mereka yang sebelumnya dianggap berada 'di luar arena'.

Perupa dengan karya-karya seni kontemporer umumnya telah menjauh dari bentuk-bentuk karya dan material konvensional sebagai medium ekspresi. Mereka memilih pengungkapan yang dapat langsung bersinggungan dengan publik, seperti seni instalasi, performance art, dan jenis-jenis seni publik menjadi bentuk pengungkapan yang penting dalam bingkai seni rupa kontemporer. Menurut Groys (2008; 71-80) seni instalasi dapat menggabungkan semua jenis benda-benda dan citraan yang beredar di dalam peradaban kita seperti: lukisan, gambar, fotografi, teks, film, rekaman, semua jenis objek dan seterusnya. Dukungan material dari medium dalam suatu instalasi bagaimanapun adalah ruang (space) itu sendiri. Sebuah instalasi adalah presentasi dari waktu kini (the present).

Pergeseran paradigma kiblat kesenian moderen menuju kontemporer, bila ditelusuri sangat dipengaruhi oleh beberapa pemikiran penting, yaitu: Pertama, berkaitan erat dengan gagasan Roland Barthes yang berpendapat bahwa sebuah teks (karya seni rupa dapat disetarakan sebagai teks) adalah suatu jaringan kombinasi makna yang otonom, yang selalu bisa ditafsirkan tanpa mengkaitkannya pada pengarangnya. Interpretasi adalah upaya membuat jaringan kombinasi baru atas jaringan yang ada. Tekslah yang memungkinkan suatu aspirasi, fiksi ataupun representasi realitas tertentu yang dapat dibaca dan karenanya berkembang biak lewat bacaan itu. Posisi teks itu otonom: dalam proses baca-tafsir teks berkembang biak sendiri dan mengalami deformasi terus menerus. Pencipta atau pengarang bukan lagi subyek atau produser, sebaliknya gambaran tentang pencipta justru dibentuk oleh teks. Teks yang direproduksi secara terus-menerus, semakin otonom, semakin tak terlalu berkaitan dengan penciptanya. Karya seni sama halnya, melalui reproduksi dan percaturan wacana kritik, karya seni menjadi sosok mandiri. Figur seniman akhirnya menjadi tak terlalu penting (Barthes, 1977; 155-164).

Kedua, berkaitan dengan konsep tentang "originalitas" atau kebaruan yang pada masa moderen menjadi semacam obsesi zaman dengan melakukan perubahan demi perubahan gaya dalam melukis dan memuncak pada kecenderungan kaum avant-gardist yang sangat eksperimental, selanjutnya kecenderungan itu perlahan berubah bersama dengan tampilnya gejala dalam sistem reproduksi seni, dengan digunakannya barang-barang yang telah siap pakai, dan orientasi lebih pada makna ketimbang pada teknik. Perubahan dalam sistem reproduksi telah memungkinkan karya dari latar budaya apapun dapat dinikmati oleh siapapun dan di manapun. Ini memungkinkan sistem referensi yang tanpa batas sehingga penciptaan menjadi makin sulit untuk sungguh-sungguh "original" bagaikan "lahir baru" seperti yang 
biasa dibayangkan kaum avant-gardist dahulu (Krauss , 1984; 18).

Penciptaan kini lebih cenderung berarti "perakitan baru" barang-barang yang siap-pakai. Walaupun terkadang menuntut tindakan "dekonstruksi", namun sebenarnya lebih menuntut tindakan "dekontekstualisasi": melepaskan unsur-unsur tertentu dari konteksnya semula kemudian merakitnya kembali dalam konteks baru yang tak terduga. Dengan perkataan lain, penciptaan kini lebih merupakan proses pembuatan kolase. Unsurunsur tertentu dihadirkan kembali dalam konteks representasi yang baru, dan dengan begitu dilepaskan dari konteks representasi aslinya. Maka lebih jelasnya lagi, yang "baru" itu akhirnya adalah "pemaknaannya", bukan pertama-tama bentuk formalnya atau pun tekniknya. Dengan demikian arah berkesenian mengalami pergeseran paradigma. Dalam konteks "bentuk dan isi", menjadi bergeser lebih ke isi, meskipun tentu saja seni rupa selalu tetaplah pada perkara "olah bentuk".

Ketiga, berubahnya pola produksi makna. Ketika penciptaan "adikarya" tidak lagi dianggap satu-satunya fokus, maka format lukisan yang akrab dengan dinding (museum) berubah ke arah format installasi, multimedia dan kecenderungan interdisipliner, maka serta merta aspek dialogis atau komunikasi menjadi lebih menonjol. Karya hadir tidak hanya untuk "ditonton", melainkan untuk didialogkan dan lebih lagi: dialami. Dalam seni kontemporer lantas "karya" lebih merupakan "peristiwa". Dalam kerangka dialogis itu otomatis sang seniman lebih berfungsi sebagai semacam "fasilitator" yang memberi umpan atau perangsang bagi penciptaan makna bersama pemirsanya. Seniman posisinya bukan lagi pusat, pusatnya adalah "makna" yang terbentuk dari interaksi dialogis antara seniman, karyanya dan persepsi penonton.

Dengan munculnya ketiga gejala tersebut, menjadi jelas bahwa paradigma representasi versi moderenisme yang berpusat pada pribadi seniman sebagai "genius", penciptaan "adikarya" yang abadi (karenanya perlu museum), originalitas sebagai diskontinuitas terhadap tradisi dan kecenderungan teknis formalistiknya yang sangat kuat, akhirnya bergeser ke paradigma representasi baru dengan segala konsekuensi ikutannya. Dengan kata lain, bila "estetika" diartikan secara sempit sebagai "kaidah-kaidah berkesenian moderen", maka pada saat ini dapat dikatakan bahwa sosok dan kiprah seni rupa kontemporer cenderung "antiestetis". Bahkan bila gejala ini memang betul, maka kecenderungan itu bersifat paradigmatis. Bisa saja dikatakan bahwa di bidang seni rupa, abad ini dan mendatang adalah abad "posestetis".

Kenyataan tentang fine arts yang eksklusif akhirnya terdobrak oleh dinamika dalamnya sendiri maupun dari interaksi luarnya yang menunjukkan bahwa fine arts yang diisolasi secara eksklusif itu sebenarnya artifisial. Perubahan paradigmatis dalam dunia seni rupa kontemporer yang memiliki keterkaitan dengan pluralitas kultur dan kehidupan sehari-hari ini pada akhirnya melahirkan ketidaktentuan. Pada 
akhirnya seni bentuknya plural, praktiknya pragmatik, dan medan-seninya multikultural, dan nyaris tak ada ukuran untuk menilai bobotnya secara universal dan seragam.

\section{B. Identitas Seni Rupa Indonesia}

Isu identitas dalam perkembangan seni rupa Indonesia senantiasa menjadi persoalan penting, bahkan sejak awal kemunculan seni rupa moderen Indonesia, sebelum masa kemerdekaan. Penentangan terhadap lukisan "Mooi Indie" serta anjuran pengembangan seni lukis ke arah "corak seni lukis Indonesia Baru" oleh S. Sudjojono dan kawan-kawan melalui Persagi merupakan upaya pencarian identitas yang didasari oleh sentimen kebangsaan. Lahirlah kemudian karya-karya lukisan ekspresif yang merupakan perwujudan dari gejolak semangat nasionalisme serta cerminan dari situasi dan kondisi pada waktu itu. Tidak pelak lagi, gerakan ini telah melahirkan genre baru seni rupa moderen Indonesia yang berbeda dari sebelumnya.

Permasalahan identitas terus menggeliat bersama dengan situasi dan kondisi negara. Masa setelah kemerdekaan muncul sanggar-sanggar seni yang terkooptasi kepentingan partai politik atau kepentingan politik lainnya, sehingga identitas yang dibangun melalui karya-karya seni, lahir dari tangan-tangan seniman yang membawa identitas ideologis kepartaian. Sebagai mana para seniman yang berada di bawah LEKRA, identitas kerakyatan dengan semangat revolusi mengemuka dengan kuatnya "Politik adalah Panglima”.
Di masa Orde Baru, masa sesudah penumpasan PKI hingga memasuki tahun 70-an persoalan identitas menjadi hal penting, tema kerakyatan sebagai implementasi membangun wacana politik menjadi kurang popular. Pemerintah Orde Baru memandang perlunya mencari suatu format identitas "Kepribadian Nasional" di dalam segala bantuk ekspresi seni. Sebagai gambaran, pada Pameran Besar Seni Lukis Indonesia 1974, dewan juri memberikan hadiah penghargaan Karya Terbaik kepada beberapa pelukis senior. Karya-karya yang hampir seluruhnya bercorak dekoratif ini mendapatkan penghargaan oleh karena dianggap memunculkan kecenderungan kuat "identitas nasional Indonesia”. Tentu saja secara tidak langsung hal ini merupakan legitimasi bagi seni lukis dekoratif untuk menjadi seni yang menampilkan identitas nasional. Inilah yang kemudian memicu aksi penentangan oleh beberapa seniman muda terhadap keputusn dewan juri, yang kemudian dikenal dengan peristiwa "Desember Hitam".

Seni Rupa (khususnya seni lukis) "moderen" yang diwakili tokoh penting seperti Raden Saleh, Basoeki Abdullah, Soedjojono, Affandi, Hendra Goenawan, dan seterusnya hingga generasi A.D. Pirous, Sadali, Widayat, Aming dan tokoh lainnya yang sangat disiplin pada aliran (isme) seni, menjadi patron. Situasi ini semakin menemukan momentumnya dengan terjadinya booming seni lukis Indonesia tahun 1980-an terutama pada seni lukis dekoratif dan abstrak yang 'cantik' yang berbeda dengan spririt yang diusung karya seni rupa kontemporer yang 
cenderung kritis dan politis. Namun demikian kehadiran seni rupa kontemporer Indonesia tidak semata-mata dalam kerangka melawan superioritas seni lukis moderen Indonesia (abstrak dan dekoratif), tetapi lebih kepada sikap responsif terhadap perkembangan seni rupa Barat yang mengesampingkan perkembangan seni rupa belahan Timur (Asia, Pasifik, Afrika) yang dipandang sebelah mata oleh Barat. Situasi ini memberi semangat para perupa muda untuk mengusung karakter karya yang berbeda dengan yang telah diusung dalam seni rupa Barat (Supangkat, 2005; 218-228).

Gerakan Seni Rupa Baru tahun 1975-an dan Pameran "Seni Rupa Kepribadian Apa" tahun 1977-an yang menjadi momentum tumbuhnya seni rupa kontemporer Indonesia, menampilkan kecenderungan yang jauh lebih bebas dalam pola-pola ungkap keseniannya, serta memperkarakan kiblat dan konsep dasar kesenian di Indonesia umumnya. Seni rupa kontemporer memberi ruang bagi perbedaan dan keberagaman, maka isu identitas menjadi persoalan krusial. Di dalam perkembangan seni rupa Indonesia pada periode tahun 80-an, persoalan identitas ini kemudian mengalami pergeseran dan menempati tempat khusus, yaitu dari "identitas nasional" yang bersifat politis menjadi “identitas kultural" yang didasarkan pada latar belakang budaya.

Berbeda dengan identitas nasional yang lebih didasari oleh sentimen kebangsaan dan tujuan politis, maka identitas kultural merupakan kesadaran akan eksistensi diri sebagai individu yang berada di antara individu-individu lain yang senantiasa saling berinteraksi. Persoalan identitas bukanlah sekedar pertanyaan mengenai apa yang membedakan kita dari orang lain, yaitu semua hal yang menyangkut asal-usul (origin), sejarah dan ingatan, melainkan juga kesadaran budaya di dalam kondisi kini maupun akan datang, oleh karena identitas akan berperan di dalam menentukan posisi dan pola hubungan antara diri kita dengan individu lain, antara "the self" dan "the other". Tradisi, mitologi, kosmologi yang hidup di masyarakat sekarang maupun masa lalu membentuk memori kolektif yang menjadi bagian dari identitas. Kepercayaan, harapan, impian, dan cita-cita juga turut membentuk sebuah identitas, sehingga dengan demikian identitaspun menjadi sesuatu yang dinamis. Menurut Stuart Hall (2000), identitas kultural merupakan akumulasi dari "identitas esensial" (yang given, bersifat statis) dan "identitas hybrid" (created, bersifat dinamis).

Tidak mudah menentukan daerah inklusi seni rupa kontemporer Indonesia, baik praktek maupun rentang waktu. Antara pengamat yang satu dengan yang lain memiliki parameter dan dan sudut pandang yang berbeda, tetapi secara garis besar dari berbagai pandangan yang berkembang dalam wacana seni rupa Indonesia, praktek seni rupa kontemporer dipahami sebagai sebuah fenomena seni rupa yang memiliki "paradigma" yang berbeda dengan seni rupa pada masa sebelumnya. Dalam hal ini yang menjadi ciri-ciri menonjol adalah meningkatnya tema sosial-politik, adanya kecenderungan anti formalism (diasosiasikan dengan gerakan Pascamoderenismee), penonjolan pluralisme 
disertai unsur-unsur lokal, dan tumbuh kembali tradisi realisme dan kecenderungan representasional (Soedarso SP, 2006; 188-190). Perubahan paradigma ini dibarengi dengan kesadaran membawa peristiwa-peristiwa pameran ke ranah internasional dengan mengangkat isu yang menjadi ketertarikan masyarakat internasional.

Perlu diperhatikan bahwa kecenderungan dalam seni rupa kontemporer Indonesia berupaya menggali inspirasi-inspirasi dasar dari khasanah tradisi yang telah tumbuh sejak seni rupa moderen dan terus menjadi spirit yang tak ada habisnya, namun tidak lagi terbelenggu dalam karakteristik yang beku sebagaimana dalam seni moderen. Upaya menggali khasanah tradisi sebagai spirit dan inspirasi penciptaan seolah menjadi amanah yang tidak pernah selesai dan menantang seniman menemukan sisi-sisi yang belum sempat dieksplorasi.

Seni rupa kontemporer Indonesia dengan jelas menampilkan multikultur dan multietnik sekaligus identitas subjek. Para perupa kontemporer Indonesia menampilkan berbagai karya yang sebagian menunjukkan pencariannya terhadap identitas keindonesiaan dan sebagian lain mengacu pada identitas etnik sebagaimana pada periode sebelumnya, serta tidak lagi berorientasi pada kategori-kategori dalam moderen art serta menuaikan yang "indahindah", namun kritis dan politis. Seni rupa kontemporer Indonesia cukup kuat merepresentasikan tema-tema resistensi sekaligus berupaya menerobos dinding-dinding tekstual. Realitas tidak lagi bisa kita tunjuk langsung untuk dengan gampang menemukan identitas diri, karena realitas selalu menampilkan multi makna dan tentu saja karena realitas tidak lain adalah jaringan tanpa tanda esensi. Subyek dalam konstruksi tekstual ini lebih baik dilihat sebagai sebuah 'identitas terbagi' dari pada 'identitas substansial' dalam jiwa moderenisme (Awuy, 2002; 92-99).

Perupa Indonesia mencari celah yang tidak dimiliki dan diisi para perupa kontemporer Barat dan mengisi dengan sesuatu yang berbeda yang dapat menunjukkan posisi tawar seni rupa Timur dengan mengusung spirit global dan menggunakan idiom-idiom lokal ke kancah internasional menjadi salah satu pembeda dengan model perkembangan seni rupa pada tataran lainnya. Kecenderungan ini menjadi kecenderungan yang umum pula dalam seni rupa kontemporer Indonesia yang dengan jelas menampilkan multikultur dan multietnik sekaligus identitas subjek. Hal ini sebagaimana terjadi pada perkembangan seni rupa kontemporer di dunia pada umumnya yang cenderung mengutamakan identitas budaya dan sosial seperti misalnya identitas etnik, identitas kaum marginal, identitas perempuan, identitas politik dan sebagainya dalam bentuk seni lukis, instalasi dan performance.

Salah satu kesimpulan dalam penelitian untuk disertasi dengan judul "Seni Rupa Kontemporer di Yogyakarta Sejak Tahun 1975 hingga 2010: Identitas dan Perubahan" oleh Hariyanto juga disebutkan bahwa para perupa Yogyakarta memainkan politik identitas dalam karya mereka. Hasil identifikasi menunjukkan 
bahwa identitas perupa Yogyakarta berdasarkan tanda-tanda yang nampak dalam karya dapat dikategorikan ke dalam beberapa identitas yaitu: identitas diaspora/migrant, identitas gender, identitas ruang publik, identitas sosial-politik, dan identitas budaya Jawa (Hariyanto, 2010).

Sejak tahun 1990-an banyak perupa kontemporer yang mengekspresikan karyanya dengan melibatkan publik sebagai bagian dari karya mereka serta mengusung karya-karya mereka keluar dari galeri dengan memanfaatkan ruang-ruang publik yang mudah diakses oleh publik. Karya-karya seni rupa kontemporer yang memberi peluang publik sebagai audiens terlibat dalam karya seni rupa, biasanya berupa karya instalasi dan performance art. Instalasi dan performance art sering dijadikan karya yang bersifat kolaboratif. Seni rupa instalasi dan performance art di Indonesia telah mendorong para perupa untuk mengangkat seni tradisi ke dalam bingkai yang lebih kritis dan politis. Seni tradisi seperti upacara dan ritual ruwatan yang selama ini hanya dianggap sebagai seni rakyat dan objek turisme, kini mendapat tempat khusus di dalam seni rupa kontemporer.

Di dalam konsep dan proses pembuatan karya tersebut perupa bekerja sama dengan perupa lain, artisan dan publik audiens. Dalam beberapa kasus perupa melibatkan dua kelompok komunitas secara bersamaan yaitu pertama komunitas yang terlibat dalam proses pembuatan dan presentasi karya, dan kedua, komunitas atau publik audiens yang menonton sekaligus ikut merasakan aktivitas yang dipresentasikan oleh perupa komunitas. Para perupa yang memanfaatkan ruang publik atau ruang-ruang alternatif tidak lagi menaruh perhatian identitas bangsa maupun neokolonialisme yang sudah dianggap kuno, mereka mengolah wacana budaya dan sosial dengan praktik artistik yang model mencomot dan menata ulang. Selain itu ada kecenderungan untuk mendaur ulang wilayah-wilayah praktik sosial dan budaya yang sampai kini belum tergali oleh wacana praktik dominan, seperti misalnya pengalaman hidup urban, budaya pop, budaya media, dan ruang gender (Rath, 2003; 4-15).

Penggunaan bahasa simbolik dalam karyakarya perupa kontemporer sangat dominan untuk mengungkapkan isu-isu sosial-politik, namun masih ada pula yang memanfaatkan tanda grafis atau teks verbal untuk memenuhi tuntutan konseptualnya. Hal ini dapat kita cermati pada karya-karya Krisna Murti, Heri Dono, Agus Suwage, Dadang Kristanto, Nindityo Adi Purnomo, kelompok Apotik Komik, Taring Padi, dsb.

\section{Budaya Majapahit sebagai Sumber Identitas}

Wilayah kekuasaan Majapahit yang begitu luas di Nusantara memberi pengaruh kuat terhadap kultur masyarakat Nusantara dalam berbagai sisi kehidupan, khususnya kesenian. Jejak-jejak arkeologis berupa artefak dan seni tradisi lainnya di berbagai wilayah nusantara menjadi bukti pengaruh Majapahit tersebut (Muljana, 2007). Namun demikian sulit untuk membuat satu simpulan bahwa seni tradisi Nusantara yang berkembang dan dapat kita 
saksikan saat ini murni pengaruh Majapahit sebagainama masa kejayaannya.

Upaya untuk terus menggali spirit budaya Majapahit sebagai bagian dari identitas suatu wilayah budaya melalui seni khususnya seni rupa bagaikan mamandang fatamorgana, tampak atau terlihat tetapi semu, apalagi pada era seni rupa kontemporer, seniman memiliki ruang presentasi dan penikmat seni memiliki ruang interpretasi yang lebih longgar dalam mengeksplorasi budayanya. Artefak hasil penelusuran arkeologis berupa prasasti, arsitektural candi, relief, kriya logam, patung, terakota, benda pusaka, ataupun yang berkaitan dengan seni pertunjukan dan sastra seperti wayang beber, wayang klitik, topeng panji, reog, jathilan, dan banyak lainnya yang diakui sebagai peninggalan budaya Majapahit dapat menjadi referensi untuk membangkitkan inspirasi penciptaan. Namun demikian tidak serta-merta karya seni yang dihasilkan para seniman yang bersumber dari kultur Majapahit dapat diakui sebagai sebuah identitas visual suatu wilayah budaya di mana si seniman berasal. Demikian halnya masyarakat penikmat karya seni juga tidak mudah mengidentifikasi sumber atau inspirasi penciptaan hanya dari identitas visual dan bahkan semakin sulit menyamakan interpretasi seperti yang dikehendaki seniman. Seni rupa kontemporer memberi keleluasaan seniman untuk melakukan reinterpretasi terhadap sebuah peristiwa atau bahkan nilai-nilai yang ada dalam artefak masa lalu, sehingga yang tersaji adalah representasi yang mungkin sangat jauh berbeda dengan sumber aslinya.
Masyarakat tradisi yang dalam catatan sejarah diyakini sebagai pelarian masyarakat Majapahit yang saat ini tinggal di kawasan Tengger dan Bali atau wilayah Mataram (Yogyakarta dan Surakarta) juga telah berkembang sesuai zaman, sehingga tidak lagi dapat dilihat sebagai kultur Majapahit saat masa kejayaannya. Barangkali hanya pada kebudayaan Bali, spirit budaya Majapahit semakin berkembang dan masyarakat Bali menganggap diri sebagai penerus sejati kebudayaan Majapahit. Di Bali misalnya, kesenian menjadi bagian yang tidak terpisahkan dari kehidupan spiritual dan sosial masyarakat. Budaya yang telah terbangun selama berabad-abad dan secara ketat dijaga dan ditaati keberlangsungannya serta tumbuh sebagai identitas diri seniman dan wilayahnya. Nama khas seniman dari Bali juga menjadi identitas yang memudahkan publik mengenali mereka, dengan menyebut beberapa nama seniman Bali seperti Ida Bagus Made, I Nyoman Tilem, I Nyoman Masriadi, publik akan mengidentifikasi sebagai seniman keturunan Bali di manapun mereka tinggal.

Budaya Bali juga mampu menjadi inspirasi penciptaan yang kuat bagi banyak seniman Bali dan seniman luar wilayah Bali, bahkan luar negeri. Objek perempuan Bali yang eksotik, upacara adat, tradisi masyarakat Bali lainnya menjadi objek yang lazim kita temui pada banyak karya maestro seni rupa Indonesia. Setiap goresan, pahatan, atau gerak imajinatif merepresentasikan dengan kuat kultur Bali. Bali telah menjadi spirit yang melekat pada ciptarasa-karsa banyak seniman. Para perupa 
kontemporer Bali juga tidak kehilangan spirit keBali-an mereka, meskipun dalam karya mereka teridentifikasi identitas-identitas lain yang menjadi tuntutan zaman, seperti gender, budaya urban, budaya media, sosial-politik, dan sebagainya. Mereka juga merepresentasikan tema-tema resistensi dengan menerobos dinding-dinding tekstual. Realitas tidak lagi sekedar menunjukkan identitas diri, tetapi ditampilkan multi makna. Subyek dalam konstruksi tekstual ini lebih baik dilihat sebagai sebuah 'identitas terbagi' dari pada 'identitas substansial'.

Bagaimana dengan Budaya Majapahit ? Spirit dan budaya Majapahit tidak dapat menjadi klaim identitas secara kewilayahan berdasarkan lokasi pusat pemerintahan Majapahit berada atau berdasarkan situs-situs Majapahit ditemukan, akan tetapi menjadi kekayaan khasanah budaya yang dapat menginspirasi berbagai macam penciptaan seni oleh seniman manapun. Budaya Bali oleh banyak kalangan diasumsikan sebagai kelanjutan peradaban Hindu Majapahit yang masih bertahan. Museum besar Majapahit tersebar hampir di seluruh wilayah Nusantara serta dapat menjadi tempat belajar dan bercermin mengenali identitas diri agar dapat membedakan dengan identitas lainnya. Berbagai peninggalan yang terdapat di situs Majapahit di Jawa Timur berupa falsafah, ilmu pengetahuan, teknologi, dan seni harus berada di tempatnya dan menjadi inspirasi penciptaan bagi siapapun yang membutuhkan. Seniman dan kriyawan di wilayah yang dekat dengan situs Majapahit dapat terus menggali khasanah budaya dari artefak yang ada, baik berupa ragam ornamentik, teknologi kriya, maupun legenda dan mitos yang melingkupinya.

Penguatan spirit Majapahit dalam penciptaan karya seni serta menjadi identitas budaya dapat terus dilakukan melalui proses reinterpretasi baik oleh komunitas maupun personal. Proses reinterpretasi seni tradisi oleh komunitas ataupun personal dapat melahirkan karya-karya baru yang mengadaptasi spirit tradisi dengan tidak kehilangan akar tradisinya. Representasi secara berkelanjutan dan konsisten terhadap spirit Majapahit oleh pelaku budaya diharapkan mampu memunculkan kembali identitas yang kuat kultur Majapahit.

\section{PENUTUP}

Isu identitas dalam perkembangan seni rupa Indonesia telah menjadi wacana penting sejak awal kemunculan seni rupa moderen Indonesia, sebelum masa kemerdekaan hingga era seni rupa kontemporer (saat ini). Pada masa pra-kemerdekaan hingga Orde Baru, isu identitas berada pada ranah "identitas nasional" yang lebih didasari oleh sentimen kebangsaan dan tujuan politis, maka dalam perkembangan seni rupa Indonesia pada periode tahun 80-an, persoalan identitas ini kemudian mengalami pergeseran dan menempati tempat khusus, yaitu dari "identitas nasional" yang bersifat politis menjadi "identitas kultural" yang didasarkan pada latar belakang budaya. Identitas cultural merupakan kesadaran akan eksistensi diri sebagai individu yang berada di antara individuindividu lain yang senantiasa saling berinteraksi. 
Persoalan identitas bukanlah sekedar pertanyaan mengenai apa yang membedakan kita dari orang lain, yaitu semua hal yang menyangkut asal-usul, sejarah dan ingatan, melainkan juga kesadaran budaya di dalam kondisi kini maupun akan datang, oleh karena identitas sangat berperan di dalam menentukan posisi dan pola hubungan antara diri kita dengan individu lain, antara "the self" dan "the other". Tradisi, mitologi, kosmologi yang hidup di masyarakat sekarang maupun masa lalu membentuk memori kolektif yang menjadi bagian dari identitas. Kepercayaan, harapan, impian dan cita-cita juga turut membentuk sebuah identitas, sehingga dengan demikian identitaspun menjadi sesuatu yang dinamis.

Spirit dan kultur Majapahit tidak dapat menjadi klaim identitas secara kewilayahan berdasarkan lokasi pusat pemerintahan Majapahit berada atau berdasarkan situs-situs Majapahit ditemukan, akan tetapi menjadi kekayaan khasanah budaya yang dapat menginspirasi berbagai macam penciptaan seni oleh seniman manapun. Majapahit menjadi museum besar yang tersebar di wilayah Nusantara, tempat belajar dan bercermin mengenali identitas diri agar dapat membedakan dengan identitas lainnya. Oleh sebab itu penguatan spirit Majapahit dalam penciptaan karya seni sebagai identitas budaya dapat dilakukan melalui proses reinterpretasi baik oleh komunitas maupun personal. Proses reinterpretasi seni tradisi oleh komunitas ataupun personal dapat melahirkan karya-karya baru yang mengadaptasi spirit tradisi dengan tidak kehilangan akar tradisinya serta menjadi strategi dalam menghadapi wacana global.

\section{DAFTAR PUSTAKA}

Awuy, Tommy F.

2002. 'Identitas Terbagi dalam Seni Rupa Kontemporer' dalam Adi Wicaksono, ed, Identitas dan Budaya Massa:Aspek-aspek Seni Visual Indonesia, Yogyakarta: Yayasan Seni Cemeti.

Barthes, Roland.

1977. Image-Music-Text. New York : Hill and Wang.

Danto, Artur C.

1995. After the End of Art: Contemporary Art and the Pale of History. Princeton, New Jersey: Princeton University Press.

Groys, Boris.

2008. 'The Topology of Contemporary Art', dalam Terry Smith, Okwui Enwezor, dan Nancy Condee, ed. Antinomies of Art and Culture: Modernity, Posmodernity, Contemporaneity. Durham \& London: Duke University Press.

Hariyanto.

2012. "Seni Rupa Kontemporer di Yogyakarta Sejak Tahun 1975 hingga 2010: Identitas dan Perubahan" Disertasi untuk memenuhi sebagai persyaratan mencapai Derajat Sarjana S.3. pada Sekolah Pascasarjana, UGM Yogyakarta.

Krauss, Rosalind E.

1984. The Originality of the Avant-Garde: A postmodernist Repetition, dalam Brian Wallis (ed) Art After Modernism: Retbinking Representation. New York : The New Museum of Contemporary Art.

Krauss, Rosalind E.

1985. The Originality of the Avant Garde and Other Modernist Myths. Cambridge, Massachusetts: MIT Press.

Muljana, Slamet. 
2007. Runtubnya Kerajaan Hindhu-Jawa dan Timbulnya Negara-negara Islam di Nusantara (cet. IV). Yogyakarta: LKiS.

Rath, Amanda Katherine.

2003. 'Perihal Seni Alternatif dan Ruang Seni Alternatif, Jurnal Karbon, edisi 5, No. 5.

Soedarso Sp.

2006. Trilogi Seni, Penciptaan Eksistensi dan Kegunaan Seni. Yogyakarta: Badan Penerbit ISI Yogyakarta.

Supangkat, Jim.

2005. 'Art and Politics in Indonesia' dalam Turner, Caroline, Art and Social Change: Contemporery Art in Asia and Pasific. Canbera: Pandanus Books. 